\title{
PEMBUATAN MESIN PENGERING KELAPA MENGGUNAKAN SUMBER ENERGI TERBARUKAN UNTUK MENINGKATKAN PENDAPATAN MASYARAKAT KECAMATAN PONDOK KELAPA KABUPATEN BENGKULU TENGAH
}

\section{MANUFACTURE COCONUT DRYING MACHINE USING RENEWABLE ENERGY SOURCES TO INCREASE THE INCOME COMMUNITY OF PONDOK KELAPA CENTRAL BENGKULU REGENCY}

\author{
Oleh: \\ Hendra $^{* 1}$, Yenni Suhartini ${ }^{2}$, Anizar Indriani ${ }^{2}$, Hernadewita $^{3}$ \\ ${ }^{* 1}$ Program Studi Teknik Mesin Fakultas Teknik Universitas Bengkulu \\ ${ }^{2}$ Program Studi Teknik Elektro Fakultas Teknik Universitas Bengkulu \\ ${ }^{3}$ Program Studi Teknik Industri Fakultas Teknik Universitas Mercubuana \\ E-mail: *h7f1973@yahoo.com
}

\begin{abstract}
IbM community service aims to help villagers to make coconut drying machine. This dryer can help people in the processing a crops product with high water content quality, hygienic, short time and are not dependent on climate or weather. This machine mechanism can help the farmers in processing coconut plantations product, especially in the process of drying the crop so that sale value of dried coconut is high and incomes become increase. In the previous drying method, the coconut is drying by the open system where as the method is dependent on natural and climatic conditions. This is very detrimental to the community because of losses in terms of drying time, the water quality and higyenis product is low and other unsecured cause dry oil prices to be low. By using a drying machine the drying time is shorter, water content and quality of drying can be controlled and hygiene will also be maintained. Increased levels of water quality and hygiene product drying will make the selling price of coconut increases. Increased selling prices will impact on people's incomes so that the welfare of society for the better copra producer. In addition to the increase in people's income, it is a national issue of poverty alleviation, employment generation and application of new technology-based products in the country will be met. This community service is done at the Village Pasar Pedati and Village Harapan District of Pondok Kelapa through training how to make the dryer machine so that people can make this tool in order to increase their income as both a producer of copra with maintained quality as well and the creator of this drying machine. From the results of devotion performed shows that the people be able to make the dryer machine with a drying time of wet coconut weighing $1.4 \mathrm{~kg}$ to $1 \mathrm{~kg}$ within 7 hours, the water content of $40 \%$ decreased to $28 \%$ and an average temperature of $65^{\circ} \mathrm{C}$.
\end{abstract}

Keywords: dried coconut drier machine, solar energy 


\section{PENDAHULUAN}

Indonesia merupakan negara kepulauan dan berada di daerah tropis yang memiliki banyak sumber daya alam seperti perkebunan, perikanan, pertambangan dan lainnya. Sumber daya alam dari hasil perkebunan termasuk sumber penghasil devisa yang besar untuk negara dan daerah-daerah di Indonesia. Daerah-daerah yang memiliki perkebunan luas akan memiliki pendapatan asli daerah yang juga tinggi. Perkebunan yang terdapat di setiap daerah di Indonesia adalah kebun sawit, karet, coklat, kelapa dan lainnya. Perkebunan kelapa sangat banyak didapati di daerah-daerah pesisir pantai. Kabupaten Bengkulu Tengah dan dan Kabupaten Bengkulu Utara termasuk dalam Provinsi Bengkulu yang daerahnya berada di dekat pesisir pantai. Kebanyakan daerah pesisir pantai ini pendapatannya diperoleh dari hasil melaut dan berkebun kelapa. Untuk kebun kelapa, hasil perkebunannya dijadikan sebagai kelapa muda dan kelapa untuk masak padahal kelapa termasuk dalam komiditi ekspor yang banyak diminati oleh negara lain (dalam bentuk kelapa kering).

Nilai ekonomis dari kelapa muda dan masak ini tidak terlalu tinggi jika dibandingkan dengan mengolah atau membuat kelapa menjadi kelapa kering (kopra). Hal ini dapat dimanfaatkan oleh masyarakat penghasil kelapa dengan cara mengolah dan mengeringkan hasil kelapanya sebelum dijual atau diekspor ke negara lain. Kendala yang sering muncul dalam hal pengolahan dan pengiriman produk kelapa kering keluar negeri adalah kadar kualitas air dan kebersihan dari produk olahan pengeringan kelapa. Karena kebanyakan masyarakat mengolah dan mengeringkan produk kelapa dengan cara alami yang membutuhkan waktu lama (1-2 hari tergantung iklim atau cuaca), dimana kualitas kadar air dan kebersihan produk pengeringannya tidak dapat dijaga dan dikontrol dengan baik (Kartasapoetra, 1989, Ananto, 1999, Sutrisno dkk., 2006). Hal inilah yang membuat produk ekspor ini tidak bernilai atau tidak diterima oleh negara lain karena mutu dan kualitas yang dihasilkan rendah (proses pengeringan yang dilakukan dialam terbuka). Selain itu di Indonesia juga sulit untuk mendapatkan kondisi pengeringan yang tetap atau konstan.

Untuk menanggulangi hal ini agar kualitas dan mutu hasil pengeringan kopra ini meningkat maka dibuat mesin pengering dengan memanfaatkan energi alternatif seperti panas energi surya (Amali et al., 2015, Gunasekaran et al., 2012, Putra dan Hadi, 2013), motor dan bahan bakar kayu, sekam padi (Tambunan, 2017 dan Sustrisno et al., 2006, Setiawan et al., 2016, Anonim, 2009, Nugraha dan Rahmat, 2008, Hermawan, 2009) yang bertujuan untuk menghasilkan produk pengeringan dengan kualitas kadar air dan mutu yang baik dan higienis. Untuk Desa Pasar Pedati dan Desa Harapan Kecamatan Pondok Kelapa, karena kekurangan dari masyarakat setempat dalam pengetahuan dan kemampuan membuat alat tepat guna untuk proses pengeringan kelapa menyebabkan masyarakat cenderung hanya menjual kelapa sebagai produk kelapa muda dan kelapa untuk masakan. Untuk menanggulangi hal ini, dalam pengabdian masyarakat IbM ini dilakukan alih pengetahuan dan teknologi cara pembuatan dan pengolahan kelapa kering menggunakan 
energi surya dan panas efek rumah kaca agar didapatkan kualitas produk yang baik dan higienis sehingga pendapatan masyarakat bertambah dan kesejahteraannya meningkat.

Produk yang dihasilkan dalam pengabdian ini adalah mesin pengering kopra dengan pemanfaatan sumber energi alternatif seperti panas dari efek rumah kaca dan energi surya dan membuka lapangan kerja baru. Selain itu pemanfaatan energi alternatif ini juga bertujuan untuk menghemat penggunaan bahan bakar minyak dan ramah lingkungan. Permasalahan yang timbul pada proses pengeringan kelapa adalah pada kendala yang terjadi pada saat proses pengeringan dilakukan (Henderson dan Perry, 1990) yaitu waktu pengeringan yang lama, área pengeringan yang luas, kualitas hasil pengeringan yang tidak konsisten dan kurang baik, kurang higienis dan membutuhkan operator yang banyak membuat masyarakat di Kecamatan Pondok Kelapa menjadi berkurang minatnya dalam mengolah hasil kebun kelapa menjadi produk dengan nilai ekonomis yang tinggi. Masyarakat cenderung menjual produk kelapa dalam kondisi masih di atas pohon dengan harga murah tanpa mau mengolah hasil kebun kelapa menjadi kelapa olahan seperti kopra. Untuk itu dalam rangka meningkatkan pendapatan masyarakat daerah itu maka dilakukan pelatihan dalam merancang dan membuat suatu mesin pengering kelapa sederhana dalam skala kecil yang dapat dibuat dengan mudah dan digunakan untuk mengolah kelapa hasil kebun sehingga memiliki nilai jual yang tinggi.

Proses pengeringan kelapa yang pernah dihasilkan oleh beberapa peneliti adalah proses pengeringan dengan memanfaatkan briket sekam padi (Anonim, 2009, Hermawan, 2009, Nugraha dan Rahmat, 2008) yang dibakar dalam tungku pembakaran dan energi surya. Proses pengeringan kelapa dengan mesin ini sangat sederhana dan hasil yang diperoleh lebih baik dibanding dengan proses pengeringan alami.

Faktor-faktor yang harus diperhatikan dalam pembuatan mesin pengering kelapa adalah:

1. Mekanismenya sederhana

2. Ongkos pembuatan dan perawatan lebih murah dan material komponennya mudah diperoleh.

3. Mudah dalam pengoperasiannya.

Untuk menanggulangi permasalahan tentang pembuatan mesin pengering ini maka dilakukan pelatihan pembuatan model pengering yang sederhana, murah dan mudah dibuat.

\section{METODE PENGABDIAN}

Metode pelaksanaan pengabdian masyarakat adalah menggunakan metode presentasi dan pelatihan pembuatan produk dengan menggunakan peralatan yang sederhana seperti gergaji, palu, obeng, tang dan alat bantu lainnya. Prosedur pengabdian dapat dilihat pada Gambar 1. Tahapan pelaksanaan pelatihan meliputi:

1. Pelatihan pengenalan komponen mesin pengering kelapa 
Proses pelatihannya adalah pengenalan komponen mesin pengering yang digunakan seperti:

a) Rumah pengering

b) Pipa pengalir panas dan material

c) Rak pengering dan material

d) Ruang pengering dan material

e) Kaca untuk proses penerus panas dari matahari dan alat perangkap panas dari efek rumah kaca

2. Pelatihan perancangan dan pembuatan alat pengering kelapa

Prosedur pelatihan ini meliputi:

a) Perancangan mesin pengering kelapa dalam gambar teknik.

b) Pembuatan dan assembly komponen mesin pengering kelapa.

c) Pengujian mesin pengering dengan pemaanfaatan kelapa.

d) Memanfaatkan energi panas surya sebagai media penghasil panas.

3. Pelatihan pembuatan kolektor matahari

Prosedur pelatihan yaitu:

a) Pelatihan pembuatan kolektor matahari sebagai sumber panas untuk proses pengeringan.

b) Menggunakan energi matahari sebagai media pemanas untuk mengeringkan kelapa.

4. Prosedur kerja mesin pengering yang dibuat adalah:

a) Kelapa yang sudah dibuang batoknya dengan diameter $15 \mathrm{~cm}$ atau $2 \mathrm{~kg}$ dipotong dua.

b) Susun potongan kelapa ke dalam rak-rak pengering.

c) Siapkan kolektor matahari dan rumah pengering efek rumah kaca. Temperatur keluaran briket diperhatikan maksimal $80^{\circ} \mathrm{C}$.

d) Panaskan kelapa dan cek kadar air kelapa kering dimana kadar air yang diizinkan untuk kelapa kering (kopra) adalah $6 \%$. 


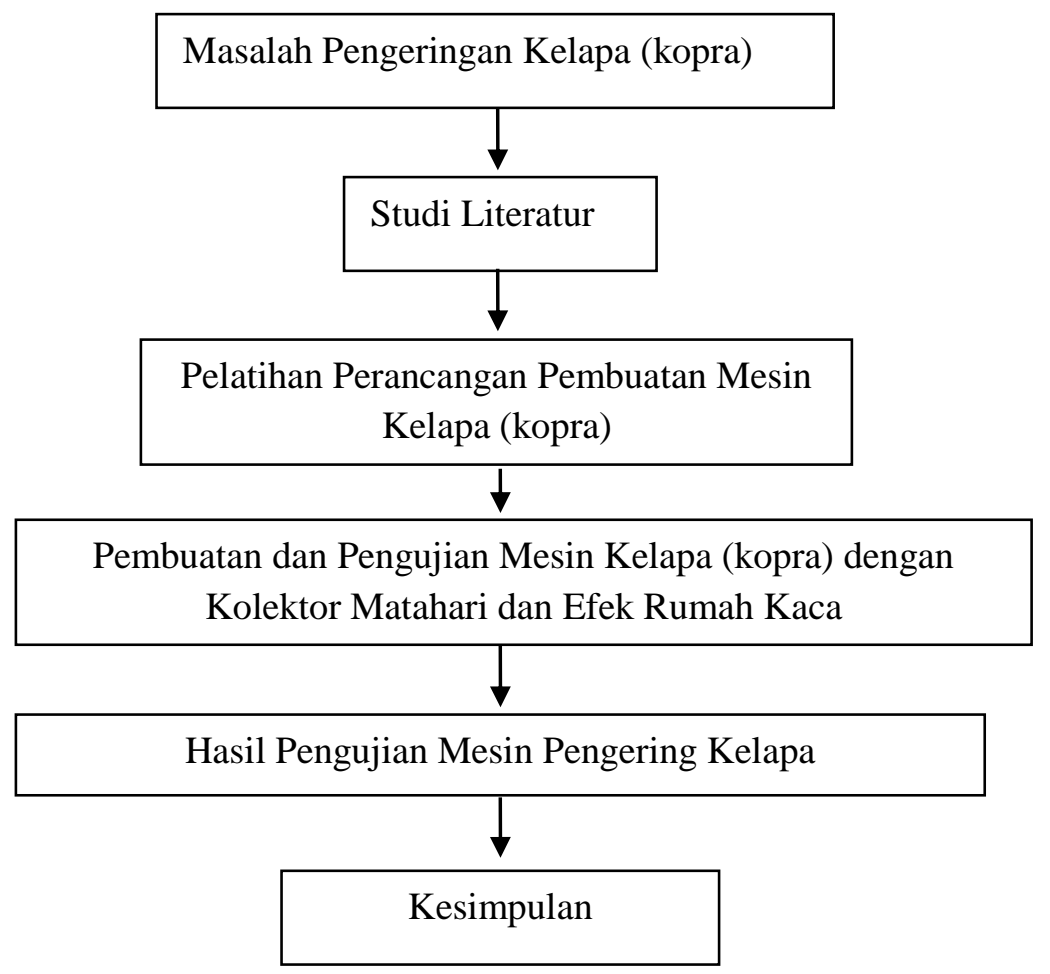

Gambar 1. Prosedur Pengabdian Masyarakat IbM

Partisipasi mitra adalah:

1. Menyediakan tempat dan fasilitas dalam menunjang kelancaran pelatihan pembuatan mesin pengering kelapa.

2. Peserta yang akan mengikuti pelatihan ini berdasarkan rekomendasi dari kelurahan.

3. Memberikan motivasi kepada masyarakat untuk mengikuti pelatihan, mengawasi dan pembina selama mengikuti kegiatan pelatihan.

4. Pada tahap pembuatan mesin pengering mitra selalu ikut berpartisipasi dalam setiap kegiatan.

Jenis luaran yang dihasilkan dalam pengabdian ini adalah peserta mampu membuat alat pengering kelapa dengan bentuk komponen dapat dilihat pada Gambar 2. Komponennya adalah:

1. Ruangan pengering terbuat dari papan untuk bagian luar dan dilapisi seng plat pada bagian dalam

2. Rumah pengering efek rumah kaca

3. Material pipa pemanas dan buang terbuat dari besi

4. Kaca sebagai bagian atas yang berfungsi untuk meneruskan panas dari matahari sekaligus alat perangkap panas untuk efek rumah kaca

5. Kolektor matahari

6. Dimensi mesin pengering yang dibuat dapat dilihat pada Gambar 2 


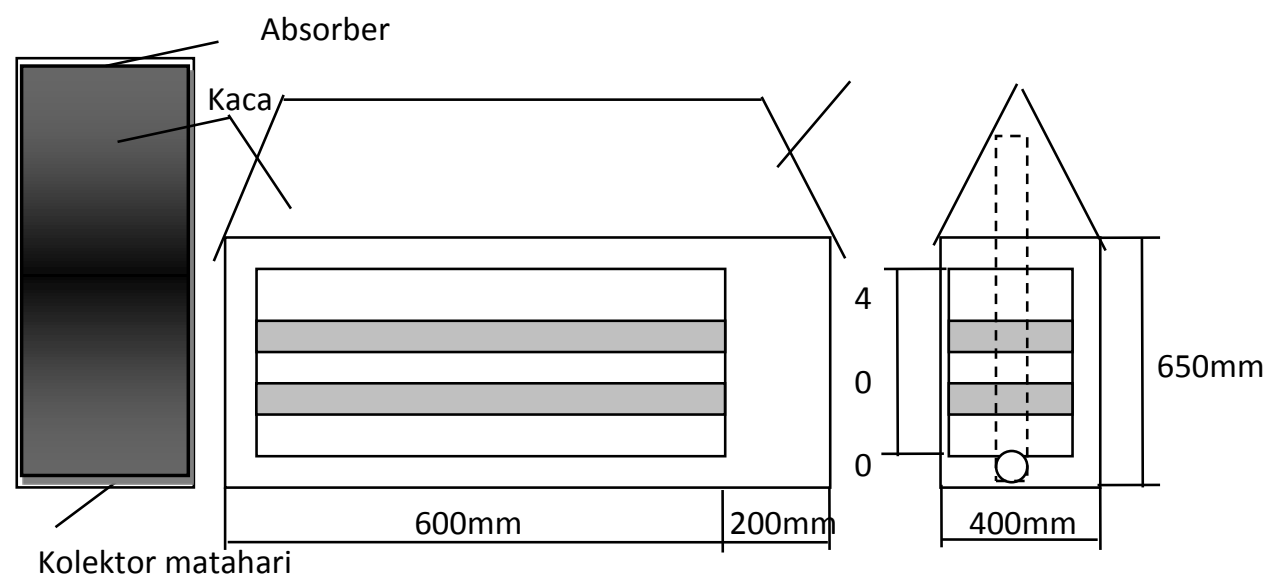

Gambar 2. Bentuk ruang pengeringan dan komponen pendukung

\section{HASIL DAN PEMBAHASAN}

\section{Hasil pelatihan}

Proses dan hasil pelatihan pembuatan mesin pengering kopra memanfaatkan energi matahari dan efek rumah kaca dapat dilihat pada Gambar 3. Pada Gambar 3 terlihat pelatihan dibuka oleh Kepala Desa dan Perangkat Desa serta diikuti oleh peserta yang terdiri dari laki-laki dan perempuan. Hal ini menunjukan pelatihan ini dapat diikuti oleh seluruh masyarakat tanpa melihat jenis kelamin dan selain itu mesin yang akan dibuat ini dapat dimanfaatkan oleh ibu-ibu disaat mengasuh anak atau mengurus rumah.

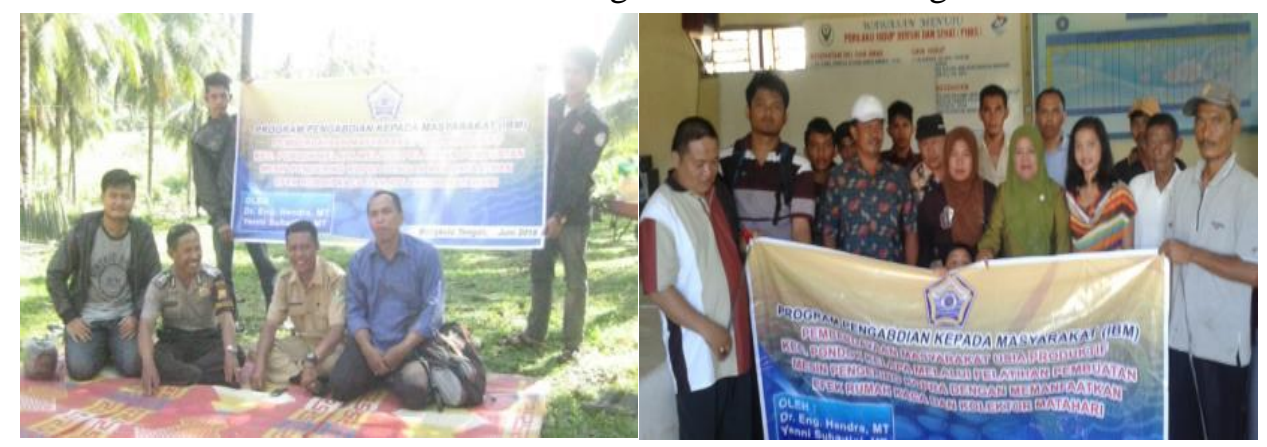

a. Kepala Desa

b. Perangkat desa

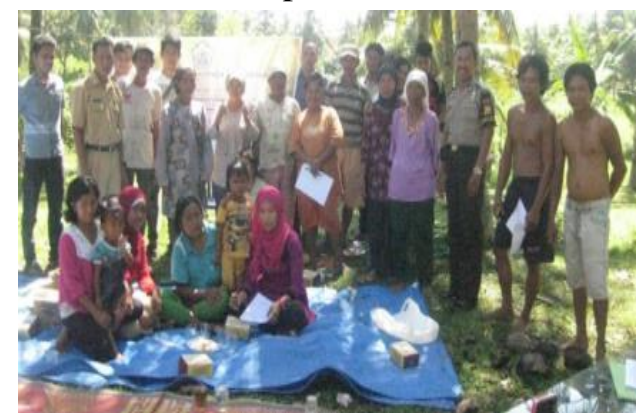

c. Peserta pelatihan

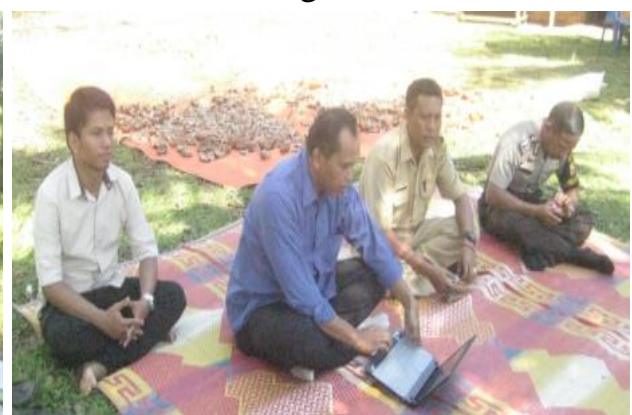

d. Pemberian materi pelatihan 
Gambar 3. Pelatihan pembuatan mesin pengering kelapa memanfaatkan energi matahari dan efek rumah kaca

Tahapan proses pelatihan meliputi pengenalan komponen mesin pengering kopra memanfaatkan energi matahari, pembuatan mesin pengering kopra, perangkaian dan pemasangan komponen. Pengenalan komponen yang dilakukan adalah:

1. Kolektor matahari

Bahan dan peralatan yang digunakan untuk membuat kolektor matahari adalah papan, seng aluminium, sirip-sirip pengalir udara, pipa besi atau pvc, kaca, spoon, cat hitam buram, kuas, fan kecil, dan peralatan bantu lainnya. Komponen itu dapat dilihat pada Gambar 4.

2. Rumah pengering (efek rumah kaca)

Gambar 5 menunjukan rumah pengering dari efek rumah kaca yang dibuat dalam pelatihan ini.
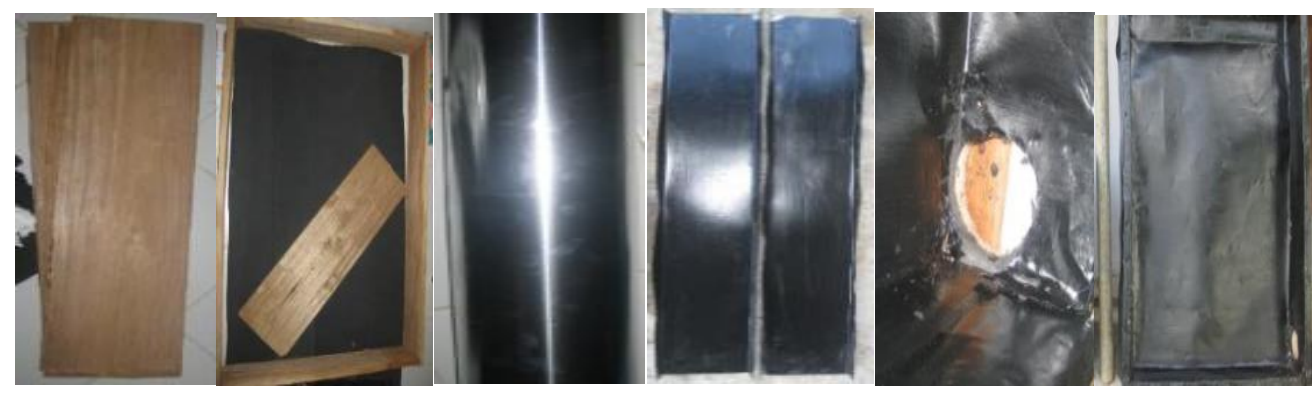

a. Bahan dan komponen kolektor matahari

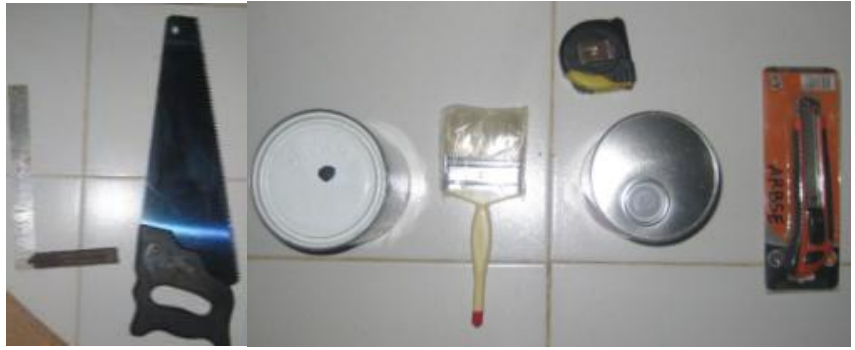

b. Peralatan bantu pembuatan mesin pengering kelapa

Gambar 4. Bahan dan Komponen Mesin Pengering Kelapa serta Peralatan Bantu

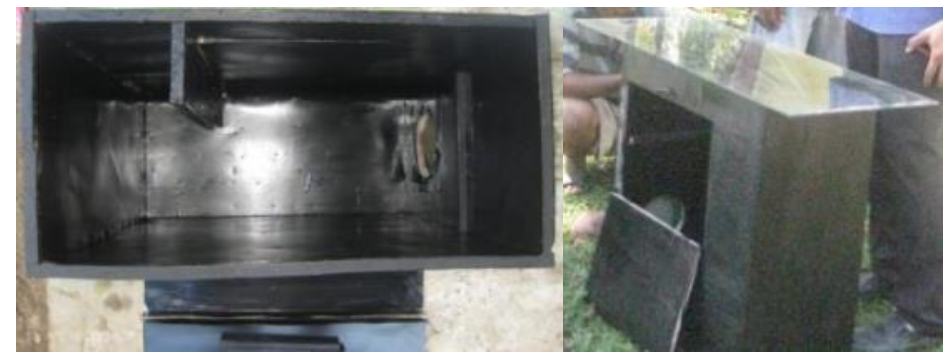

Gambar 5. Rumah Pengering Efek Rumah Kaca 
3. Perakitan dan penggabungan kolektor matahari dan rumah pengering efek rumah kaca. Komponen keseluruhan mesin pengering yang sudah dirakit dapat dilihat pada Gambar 6. Dari hasil pengujian pengeringan menggunakan mesin pengering memanfaatkan energi surya dari kolektor matahari dan efek rumah kaca diperoleh adalah untuk pengeringan kelapa basah seberat $1.4 \mathrm{~kg}$ turun menjadi $1 \mathrm{~kg}$ dalam waktu 7 jam dengan kadar air dari $40 \%$ menjadi $28 \%$ dengan temperatur rata-rata pada rumah pengering yang diterima dari kolektor matahari adalah $65^{\circ} \mathrm{C}$.

Tahapan pelatihan meliputi:

1. Pembuatan rangka kolektor matahari. Proses pembuatan rangka kolektor dapat dilihat pada Gambar 7.

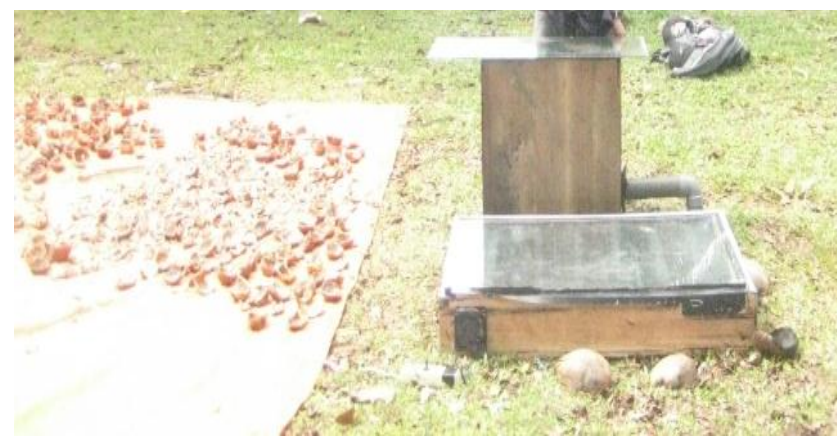

Gambar 6. Mesin pengering memanfaatkan kolektor matahari dan efek rumah kaca

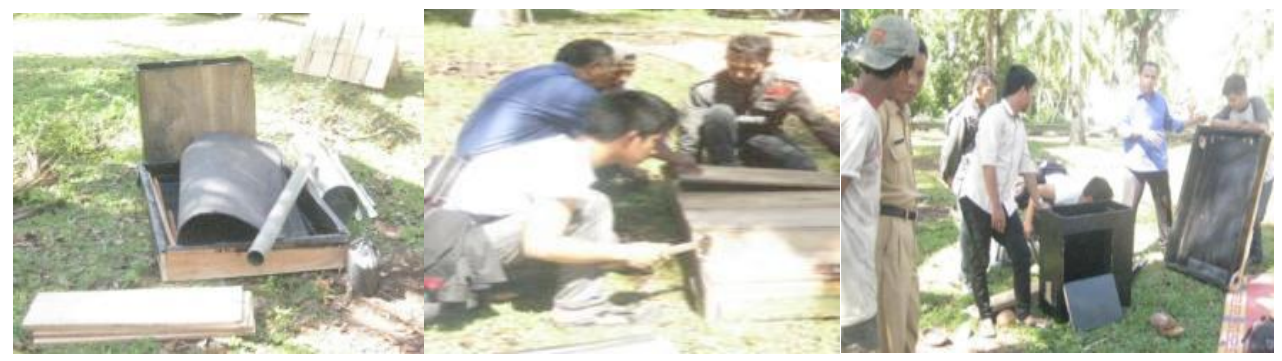

Gambar 7. Pembuatan rangka kolektor matahari

2. Pengecatan absorber kolektor matahari. Proses pengecatan absorber atau penyerap panas matahari pada kolektor dapat dilihat pada Gambar 8.

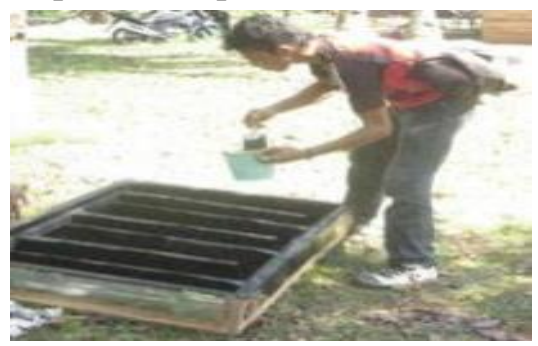

Gambar 8. Pengecatan kolektor matahari 
3. Pengecatan dan pemasangan sirip pengalir udara pada absorber. Proses engecatan dan pemasangan sirip pengalir udara pada absorber dapat dilihat pada Gambar 9.

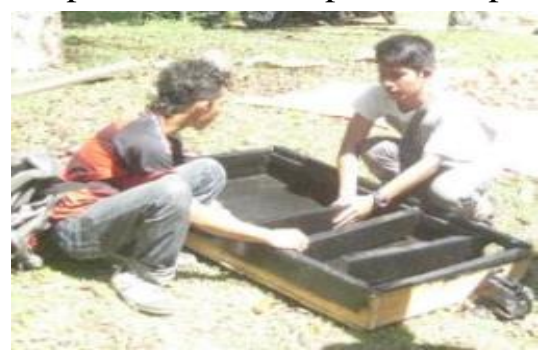

Gambar 9. Pengecatan dan pemasangan sirip pengalir udara pada absorber

4. Pemasangan kaca pelapis dan atas kolektor matahari. Proses pemasangan kaca dapat dilihat pada Gambar 10.

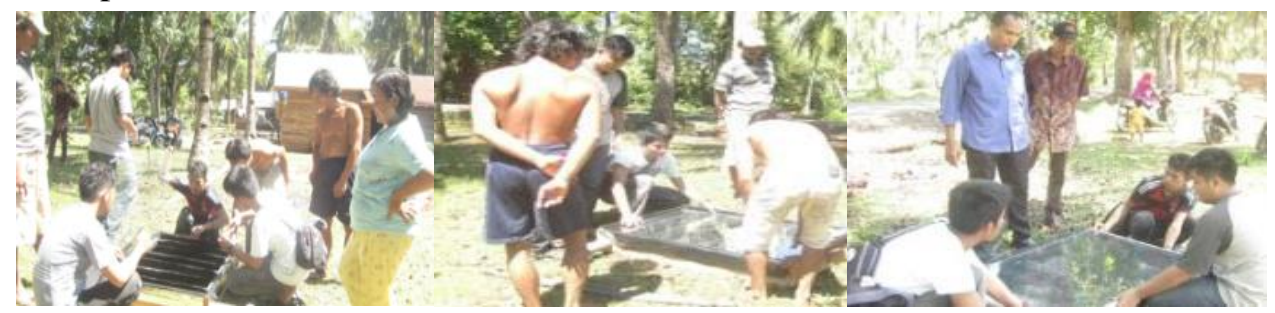

Gambar 10. Pemasangan kaca pelapis dan atas kolektor matahari

5. Pemasangan fan dan saluran pengalir sebagai pengalir udara ke rumah pengering. Proses pemasangan fan dan saluran pengalir sebagai pengalir udara ke rumah pengering dapat dilihat pada gambar 11 .

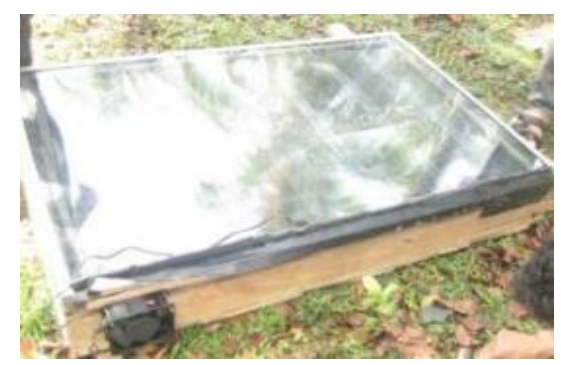

Gambar 11. Pemasangan fan dan saluran pengalir sebagai pengalir udara ke rumah pengering

6. Pembuatan rumah pengering. Pembuatan rumah pengering dapat dilihat pada gambar 12. 


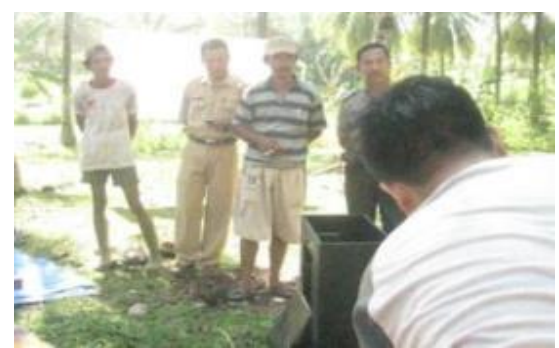

Gambar 12. Pembuatan rumah pengering

7. Pembuatan rak penyusun kelapa basah. Pembuatan rak penyusun kelapa basah dapat dilihat pada Gambar 13.

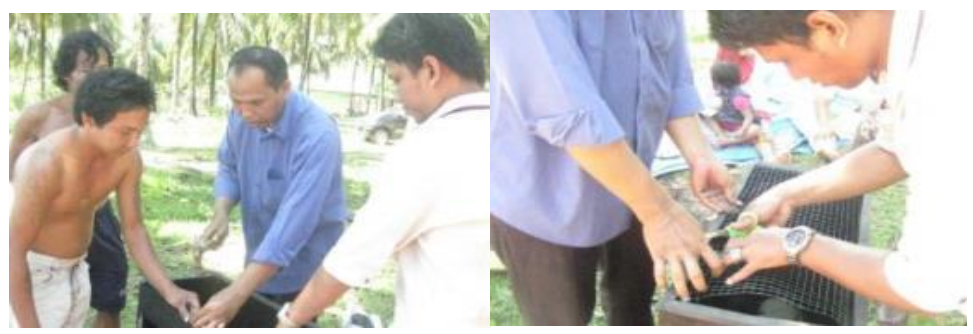

Gambar 13. Pembuatan rak penyusun kelapa basah

8. Pemasangan kaca pelapis bagian atas rumah kaca. Pemasangan kaca dapat dilihat pada Gambar 14.

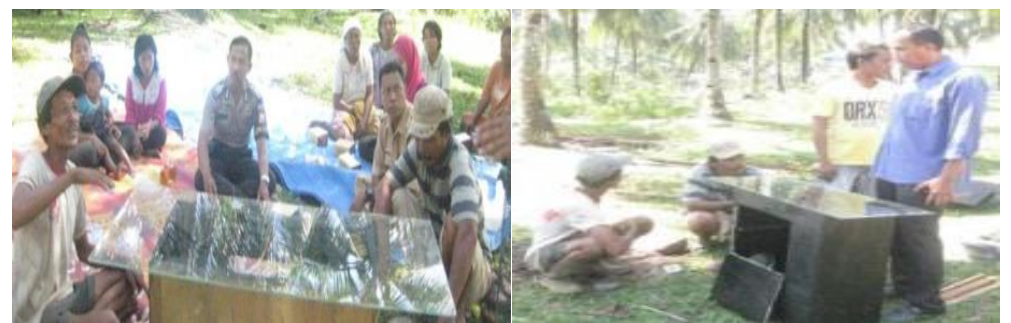

Gambar 14. Pemasangan kaca pelapis bagian atas rumah kaca

9. Perakitan kolektor matahan dan rumah pemanas.

\section{Pembahasan}

Panas yang dihasilkan oleh kolektor matahari dan rumah pengering efek rumah kaca untuk mengeringkan kelapa adalah $65^{\circ} \mathrm{C}$. Panas ini masih dalam batas yang diizinkan dalam proses pengeringan kelapa (kopra). Dimana panas ini akan dijadikan sebagai media pembakar kelapa mentah. Untuk meningkatkan panas ini dapat dengan memperluas area kolektor matahari, mengurangi kebocoran dari kolektor dan memperlambat aliran udara yang mengalir kedalam kolektor matahari dan rumah kaca.

Dari hasil pelatihan dan pembuatan mesin pengering kelapa memanfaatkan energi surya melalui kolektor matahari dan efek rumah kaca sudah memberikan dampak ke masyarakat. Dalam hal waktu pengeringan dan kadar air terlihat bahwa alat ini sudah dapat bekerja dengan baik. Dimana waktu yang dihasilkan akan dapat dipersingkat dengan 
membuat area kolektor matahari dan rumah pengering efek rumah kaca lebih besar sehingga energi matahari yang masuk juga lebih banyak diserap oleh abosrber. Selain itu pada saat pengujian terlihat masih ada kebocoran udara panas yang timbul akibat media isolasi tidak rapat menutup permukaan kaca sehingga panas yang dihasilkan berkurang.

Dari pelatihan ini terlihat antusiasme masyarakat dalam alih teknologi dimana awalnya masyarakat merasa peralatan ini susah dan mahal dibuat tetapi di lapangan terlihat masyarakat dapat membuat alat ini dengan baik dan juga terlihat dari pertanyaan masyarakat tentang kebersihan produk yang dihasilkan adalah lebih baik dibanding dengan pengeringan di alam terbuka.

\section{KESIMPULAN DAN SARAN}

\section{Kesimpulan}

Dari pelatihan dan pembuatan alat yang dilakukan dihasilkan beberapa kesimpulan yaitu:

1. Masyarakat Desa Pedati dan Desa Harapan dapat membuat alat pengering sederhana dengan konsep pemanfaatan sinar surya melalui kolektor matahari dan rumah pengering efek rumah kaca dengan kualitas produk yang dihasilkan lebih bersih dan baik dalam waktu yang lebih pendek.

2. Kadar air kelapa mentah yang dihasilkan dengan mesin pengering ini adalah $28 \%$ dalam waktu 7 jam dengan temperatur pengeringan rata-rata $65^{\circ} \mathrm{C}$.

3. Masyarakat mulai memahami prinsip kerja mesin pengering memanfaatkan kolektor matahari dan efek rumah kaca.

\section{Saran}

Pelatihan ini diharapkan dapat dilakukan secara kontinu karena masyarakat sangat terbantu dengan adanya pelatihan ini dan selalu dikawal dalam setiap aktivitasnya.

\section{DAFTAR PUSTAKA}

Amali L. M. K, Mohamad, Y. dan Harun, E. H. 2015. Karakteristik Potensi Energi Surya dan Energi Angin Pada Lahan Potensil Agropolitan yang Belum Dimanfaatkan, SETRUM - Volume 4, No. 2 thn 2015.

Ananto, E. 1999. Perbaikan Penanganan Panen dan Pasca Panen di Lahan Pasang Surut Sumatera Selatan. Proyek Sistem Usaha Pertanian Lahan Pasang Surut Sumatera Selatan. Badan Penelitian dan Pengembangan Pertanian. Departemen Pertanian. Anonim. 2009. Sekam Padi Sebagai Sumber Energi Alternatif dalam Rumah Tangga Petani. http://www.litbang.deptan.go.id/artikel/one/210/pdf/Sekam-Juni, 2009 
Gunasekaran K, Shanmugan, V and Suresh, P. 2012. Modelling and Analytical Experimental Study of Hybrid Solar Dryer Integrated with Biomass Dryer for Drying Coleus Forskohlii Stems. IPCSIT 28: 28-32

Henderson, S.M. dan Perry. 1990. Agricultural Process Engineering. New York; John Willey and Sons, Ltd

Hermawan, Y. 2009. Pemanfaatan Limbah Sekam Padi Sebagai Bahan Bakar Dalam Bentuk Briket, http://fisika.brawijaya.ac.id/bss- ub/proceeding/ Juni 2009

Kartasapoetra. 1989. Teknologi Penanganan Pasca Panen. Bumi Aksara. Jakarta

Nugraha, S dan R. Rahmat. 2008. Energi Mahal, Manfaatkan Briket Arang Sekam, Warta Penelitian dan Pengambangan Pertanian Vol 30. No 4 thn 2008. Hal 1-2

Putra I. E., dan Hadi P. 2013. Analisa Efisiensi Alat Pengering Tenaga Surya Tipe Terowong Berbantukan Kipas Angin Pada Proses Pengeringan Biji Kopi, Jurnal Teknik Mesin Vol. 3, No. 2 thn 2013. Hal: 22-25.

Setiawan Y., W. Eka Sari, Wahyudi, I., Mustofa, A. 2016. Pengeringan Lada Pada Mesin Pengering Dengan Variasi Putaran Motor, Flywheel Jurnal Teknik Mesin Untirta Vol 2. No. 1 thn 2016.

Sutrisno, dkk. 2006. Manajemen Pasca Panen Padi di Lahan Pasang Surut Sumatera Selatan untuk Mendapatkan Beras dan Benih Berkualitas. Balitpa Sukamandi.

Tambunan A. H. dan Darmawan, I. W. 2017. Energi dan Teknologi untuk Pertanian Industrial Berkelanjutan, Penerbit IPB Press, IPB Science Park Taman Kencana, Kota Bogor - Indonesia, ISBN: 978-602-440-047-7 